\title{
New from the
}

\section{International African Institute}

\section{An African Niche Economy} Farming to Feed Ibadan 1968-88

\author{
Jane I. Guyer
}

Hbk 0748609318 224pp $\quad 39.50$ June 1997

Of the several forces reshaping West African rural societies and economies in the post-colonial period, one of the most pervasive is the rapid growth of urban demand. This book studies a Yoruba community in the supply hinterland of Ibadan over twenty years. It tells the social and agricultural history of its various producers, from the Nigerian civil war, via the oil boom and bust, to structural adjustment.

It argues that principles of occupational organisation inherited from the past are now being applied to the creation of a competitive and responsive regional market that promises to be one of the most important social forms in West Africa's future.

International African Library

Jane I. Guyer directs the Program of African Studies at Northwestem University.

\section{Edinburgh University Press \\ 22 George Square, Edinburgh EH8 gLF http: //www.ed.ac.uk/ eup}

